\title{
Electrochemical and UV/VIS Study of L-Histidine and Its Complexes with Cobalt and Nickel
}

\author{
Martina Medvidović-Kosanović, * Anamarija Stanković,\# Marija Jozanović, Mateja Drulak, Marina llić
}

Department of Chemistry, J. J. Strossmayer University of Osijek, Ulica cara Hadrijana 8/A, HR-31000 Osijek, Croatia

* Corresponding author's e-mail address: mmkosano@kemija.unios.hr

\# Corresponding author's e-mail address: astankovic@kemija.unios.hr

RECEIVED: September 25, 2018 * REVISED: December 5, 2018 * ACCEPTED: December 14, 2018

Proce eding of the $5^{\text {тн }}$ Day of Electrochemistry and 8 ${ }^{\text {th }}$ ISE SSRSE, 25 May 2018, Zagreb, Croatia

\begin{abstract}
In this work oxido-reduction properties of L-histidine were studied by cyclic and differential pulse voltammetry in a pH range from $\mathrm{pH}$ 4-10. The results have shown that L-histidine is not electroactive in a pH range from $\mathrm{pH} 4$ to $\mathrm{pH}$ 9, while oxidation peak of L-histidine's imidazole ring at $\mathrm{pH} 10$ was detected with differential pulse voltammetry. It has been found that the oxidation peak current of L-histidine increased with the increase of its concentration in a solution. Adsorption of oxidation product of L-histidine on a glassy carbon electrode surface was also detected. Voltammetric techniques (cyclic and differential pulse voltammetry) and UV/VIS spectroscopy were used to study formation of L-histidine complexes with transition metals. It has been found that L-histidine formed octahedral complex with metal ion $\left(\mathrm{Co}^{2+}\right.$ and $\left.\mathrm{Ni}^{2+}\right)$ in a $1: 1$ ratio.
\end{abstract}

Keywords: cyclic and differential pulse voltammetry, L-histidine, metal complexes.

\section{INTRODUCTION}

-HISTIDINE (His) is an essential amino acid which protects human cells against oxidation stress. His is one of the strongest metal coordinating ligands among the amino acids and plays an important role in the binding of metal ions by proteins. Most of the active sites of the biomolecules have histidine as one of the amino acid residues. It has three potential metal- binding sites, namely, carboxylate oxygen, imidazole imido nitrogen and amino nitrogen. His residue is often found at the active site of enzymes, due to the high reactivity of its imidazole group and is involved directly in catalysis. ${ }^{[1]}$ It controls the transmission of metals in biological bases and can act as a neurotransmitter or neuromodulator in central nervous system of mammalians. ${ }^{[2]}$ Among all, histidine is included in numerous biochemical processes and is also present in blood serum where it carries copper and other metals between blood and tissue.[3] Varying amounts of heavy metals are required by living organisms. Human organism requires iron, cobalt, copper, manganese, molybdenum, nickel, zinc etc., while all metals have toxic effects at higher concentrations. ${ }^{[4]}$
Nickel is a micronutrient that increases hormone activity and it is involved in lipid metabolism and as a central atom of bacterial enzymes participates in degradation of urea. ${ }^{[5]}$ Cobalt is a trace element that is required for normal functioning of the pancreas, the formation of hemoglobin, absorption of iron and is a component of vitamin B12. ${ }^{[6,7]}$ Most of these transition metals are fed exclusively by food in the human body. Nickel is found in cocoa powder and in chocolate. The food with which we introduce the most cobalt in the organism is milk and dairy products. ${ }^{[8]}$

Complexes of metal cations with amino acids can be used as models in order to study the pharmacological effects of drugs. Formation of such complexes can lower toxic effects of some metal ions. ${ }^{[9,10]}$ Amino acid coordinates to metals, which confirms structural lability and can be applied in enzyme inhibition. ${ }^{[11-13]}$ These complexes exhibit significant pharmacological and toxicological properties that have attracted a lot of current attention. ${ }^{[14-17]}$

Electrochemical techniques (polarography, stripping voltammetry methods, chronoamperometry; cyclic, differential pulse and square wave voltammetry), were used to study amino acids and metal ions. ${ }^{[18-21]}$ The groups of 
Esteban and Rodriguez have used mercury electrodes to study speciation of metal ions $\left(\mathrm{Cd}^{2+}, \mathrm{Zn}^{2+}\right)$ and peptides (e.g. glutathione, metallothionen fragments such as Lys-Cys-ThrCys-Cys-Ala). They have concluded that the speciation in solution is complex and that thiol groups from the cysteines in peptides had a crucial role in metal binding. In some other electrochemical studies, metal ions were used as electroactive label for detection of amino acids and peptides in metal-peptide binding. Complexation of amino acids with metal ions gave a very low detection limit, $0.6 \mathrm{nM}$ $\mathrm{Cu}^{2+}$, which showed that amino acids and peptides could be used as selective ligands for the detection of metal ions. ${ }^{[18,22]}$

Clark et al. have studied electrochemical properties of L-histidine $\left(c=8 \times 10^{-3} \mathrm{~mol} \mathrm{dm}^{-3}\right)$ by square wave and cyclic voltammetry at physiological $\mathrm{pH}$ 7.4. ${ }^{[20]}$ They have reported two partially resolved L-histidine oxidation peaks obtained by square wave voltammetry and poor resolution obtained by cyclic voltammetry. Complexation with $\mathrm{Zn}^{2+}$ in a $1: 2$ ratio was investigated and the formation of complex was confirmed by $50 \mathrm{mV}$ positive peak potential shift when $\mathrm{ZnSO}_{4}$ was added in a L-histidine solution in a $2: 1$ molar ratio.

Sóvágó et al. have investigated copper (II) complexes of three dipeptides (HA) containing L-histidine (L-carnosine, L-histidylglycine and glycyl-L-histidine) by potentiometry, UV/VIS, IR and ${ }^{1} \mathrm{H}$ NMR spectroscopy and calorimetry. ${ }^{[23]}$ They confirmed formation of dimeric complex $\left[\mathrm{Cu}_{2} \mathrm{~A}_{2} \mathrm{H}_{-2}\right]$ when complexation of copper with L-carnosine and L-histidylglycine dipeptides was studied. In case of copper complexation with glycyl-L-histidine, $\left[\mathrm{CuA}_{2}\right] \mathrm{com}$ plex was formed. They have also concluded that deprotonation of the peptide group in the dipeptide was the easiest to achieve in the $\mathrm{Cu}^{2+}$ complex with L-histidylglycine dipeptide.

In our previous research complexation of L-histidine, $\beta$-alanine and L-carnosine with copper (II) in a phosphate buffer $\mathrm{pH} 10$ by voltammetric techniques (cyclic and differential pulse voltammetry) and UV/VIS spectroscopy was studied. ${ }^{[21]}$ We have concluded that complexation of L-carnosine and L-histidine with $\mathrm{Cu}^{2+}$ ion in a $1: 1$ ratio occurred, while no complexation of copper (II) with $\beta$-alanine was observed.

Based on previous findings, we have studied oxidoreduction properties of L-histidine in a wider $\mathrm{pH}$ range from $\mathrm{pH} 4-10$, by cyclic and differential pulse voltammetry. The L-histidine showed electrochemical activity only at $\mathrm{pH} 10$, so complexation of histidine with transition metal ions $\left(\mathrm{Co}^{2+}\right.$ and $\mathrm{Ni}^{2+}$ ) was studied in a buffer at $\mathrm{pH} \mathrm{10,} \mathrm{by} \mathrm{cyclic} \mathrm{and}$ differential pulse voltammetry and UV/VIS spectroscopy.

Since electrochemical techniques were rarely used in investigation of L-histidine and its metal complexes, the aim of this work was to give more information regarding electrochemical properties of L-histidine and formation of its metal complexes in a solution. L-histidine is involved in many important biochemical processes and its metal chelation properties are important for lowering toxic effects of metal ions, so the results of this study could find application in biological systems.

\section{EXPERIMENTAL}

\section{Chemicals and Solutions}

All commercially available chemicals were of reagent grade and used as purchased. L- histidine ((S)-2-Amino-3-(4imidazolyl) propionic acid), nickel (II) nitrate hexahydrate $\left(\mathrm{Ni}\left(\mathrm{NO}_{3}\right)_{2} \cdot 6 \mathrm{H}_{2} \mathrm{O}\right)$, cobalt (II) nitrate hexahydrate $\left(\mathrm{Co}\left(\mathrm{NO}_{3}\right)_{2} \cdot 6 \mathrm{H}_{2} \mathrm{O}\right)$ and sodium tetraborate decahydrate $\left(\mathrm{Na}_{2} \mathrm{~B}_{4} \mathrm{O}_{7} \cdot 10 \mathrm{H}_{2} \mathrm{O}\right)$ were purchased from Sigma-Aldrich, USA. Sodium hydroxide $(\mathrm{NaOH})$, sodium hydrogen carbonate $\left(\mathrm{NaHCO}_{3}\right)$ and sodium acetate $\left(\mathrm{CH}_{3} \mathrm{COONa}\right)$ were obtained from T.T.T., Croatia. Acetic acid $\left(\mathrm{CH}_{3} \mathrm{COOH}\right)$, disodium hydrogen phosphate $\left(\mathrm{Na}_{2} \mathrm{HPO}_{4}\right)$ and hydrochloric acid $(\mathrm{HCl})$ were purchased from Kemika, Croatia.

Stock solutions of L-histidine, cobalt(II) nitrate and nickel(II) nitrate ( $\left.c=1 \times 10^{-2} \mathrm{~mol} \mathrm{dm}^{-3}\right)$ were prepared in high purity water from a TKA, GenPure Ultra Pure Water System (TKA, Niederelbert, Germany), resistivity greater than or equal to $18 \mathrm{M} \Omega \mathrm{cm}$. Solutions were diluted with buffer to the desired concentration before each measurement.

Buffer solutions were prepared by means of respective analytical protocols: acetate buffer $(\mathrm{pH} 4,5$ and 6) $\left(\mathrm{CH}_{3} \mathrm{COOH}+\mathrm{CH}_{3} \mathrm{COONa}\right)$; phosphate buffer $(\mathrm{pH} 7$ and 8) $\left(\mathrm{NaH}_{2} \mathrm{PO}_{4}+\mathrm{NaHPO}\right)$; borate buffer $(\mathrm{pH} 9)\left(\mathrm{Na}_{2} \mathrm{~B}_{4} \mathrm{O}_{7} \cdot 10 \mathrm{H}_{2} \mathrm{O}\right.$ $+\mathrm{HCl})$; carbonate buffer $(\mathrm{pH} 10)\left(\mathrm{NaHCO}_{3}+\mathrm{NaOH}\right) .{ }^{[24]}$

\section{Instrumentation}

Electrochemical experiments were performed on PalmSens potentiostat/galvanostat (PalmSens BV, Utrecht, The Netherlands) driven by PSTrace 4.2 software. A three-electrode electrochemical cell was used with a glassy carbon (geometrical area $0.018 \mathrm{~cm}^{2}$ ) as a working electrode, $\mathrm{Ag} / \mathrm{AgCl}$ (inner electrolyte solution $3 \mathrm{~mol} \mathrm{dm}^{-3} \mathrm{NaCl}$ ) as a reference electrode and a platinum wire as a counter electrode. The experiments were performed in inert atmosphere (pure argon was purged before each measurement). The glassy carbon working electrode was electrochemically cleaned in $1 \mathrm{~mol} \mathrm{dm}^{-3} \mathrm{H}_{2} \mathrm{SO}_{4}$ (10 cycles, scan rate $50 \mathrm{mV} \mathrm{s}^{-}$ 1 from $-1.0 \mathrm{~V}$ to $1.0 \mathrm{~V}$ vs. $\mathrm{Ag} / \mathrm{AgCl}$ electrode). Cyclic voltammetry scan rate varied from $50 \mathrm{mV} \mathrm{s}^{-1}$ to $300 \mathrm{mV} \mathrm{s}^{-1}$. The differential pulse voltammetry conditions were: scan increment $5 \mathrm{mV}$, pulse amplitude $25 \mathrm{mV}$, pulse width $70 \mathrm{~ms}$ and scan rate $5 \mathrm{mV} \mathrm{s}^{-1}$.

UV/VIS spectra were recorded on a UV-1700 Pharma Spec spectrophotometer (Shimadzu, Japan). Standard 
solutions were diluted with a buffer $\mathrm{pH} 10$ to $c=$ $4 \times 10^{-3} \mathrm{~mol} \mathrm{dm}^{-3}$ and recorded from $200 \mathrm{~nm}$ to $1000 \mathrm{~nm}$ using standard $1.00 \mathrm{~cm}$ quartz cells.

\section{RESULTS}

\section{Electrochemical Properties of L-Histidine}

Oxido-reduction properties of L-histidine were studied in a $\mathrm{pH}$ range from $\mathrm{pH} 4-10$. The results of cyclic voltammetry have shown that L-histidine was not electroactive in the studied $\mathrm{pH}$ range (Figure $1 \mathrm{~A}$ ), while the results of differential pulse voltammetry revealed one oxidation peak (A1) at $\mathrm{pH} 10$ at the potential $E_{\mathrm{p}, \mathrm{a}}=0.860 \mathrm{~V}$ (Figure 1B). This oxidation peak corresponded to the oxidation of the imidazole ring of L-histidine which agrees with Chen, Chang et al. who also noticed imidazole ring electrochemical activity at higher positive potentials and with the results of our previous research (Medvidović-Kosanović et al. 2018).[21,25] Electrochemical activity of L-histidine was not detected by differential pulse voltammetry in a $\mathrm{pH}$ range from $\mathrm{pH}$ 4-9. L-histidine's electrochemical inactivity in a $\mathrm{pH}$ region from pH 4-9 showed that only fully deprotonated form of L-histidine $\left(\mathrm{L}^{-}\right)$was involved in oxidation reaction, while partially deprotonated forms of L-histidine $\left(\mathrm{LH}_{2}{ }^{+}\right.$and $\left.\mathrm{LH}\right)$ didn't participate in oxido/reduction processes.

The influence of L-histidine concentration on anodic peak potential and anodic peak current was studied by differential pulse voltammetry in a buffer $\mathrm{pH} 10$ (Figure 2). At this $\mathrm{pH}$ value L-histidine was completely deprotonated. ${ }^{[26]}$ It was determined that both anodic peak current and anodic peak potential increased with the increase of L-histidine concentration. It can be seen from the inset of Figure 2 that at lower L-histidine concentration (less than $c \sim$ $4 \times 10^{-4} \mathrm{~mol} \mathrm{dm}^{-3}$ ) the anodic peak current is a linear

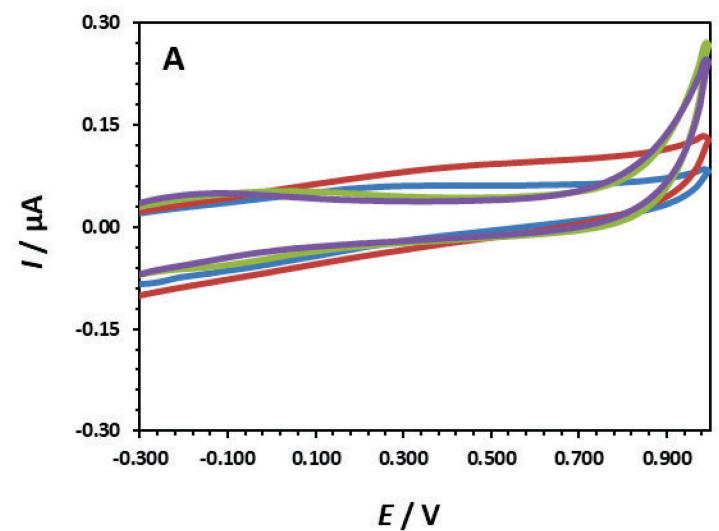

function of concentration, which indicates the adsorption of L-histidine's oxidation product on the glassy carbon electrode surface. At higher concentration region (above $c \sim 4 \times 10^{-4} \mathrm{~mol} \mathrm{dm}^{-3}$ ), peak current is levelling off, which could be explained by increasing interactions between molecules adsorbed on the glassy carbon electrode surface and L-histidine oxidation product molecules, which diffuse from bulk solution to the working electrode surface. Similar result was obtained in our previous research with rutin. ${ }^{[27]}$

Complexation studies of L-histidine and metal cations $\left(\mathrm{CO}^{2+}\right.$ and $\left.\mathrm{Ni}^{2+}\right)$ at $\mathrm{pH} 10$ could be applied to alkalosis conditions in small animals (e.g. metabolic alkalosis) when physiological $\mathrm{pH}$ value changes from $\mathrm{pH} 7.4$ to higher values. ${ }^{[28]}$

\section{Characterization of Metal Complexes CYCLIC VOLTAMMETRY}

Complexation of L-histidine with transition metal ions, $\mathrm{Co}^{2+}$ and $\mathrm{Ni}^{2+}$ in a buffer $\mathrm{pH} 10$ in $1: 1$ ratio was investigated. The L-histidine as a ligand has three potential coordination sites: the amino nitrogen $\left(\mathrm{p} K_{\mathrm{a}}=9.18\right)$, the imidazole nitrogen $\left(p K_{a}=6.0\right)$, and the carboxylate oxygen atoms $\left(p K_{a}=\right.$ 1.8). ${ }^{[26]}$ All these sites are available to coordination at the investigated $\mathrm{pH}$ value. The cyclic voltammogram of L-histidine complex with cobalt (Figure $3 \mathrm{~A}$ ) showed one anodic peak (A1) at the potential, $E_{\mathrm{p}, \mathrm{a}}=0.550 \mathrm{~V}$ which corresponded to the irreversible oxidation of cobalt in a complex, while cobalt(II) nitrate showed no oxidation/reduction peaks at this $\mathrm{pH}$ value. The cyclic voltammogram of nickel(II) nitrate (Figure $3 \mathrm{~B}$ ) revealed one anodic peak (A1) at the potential, $E_{\mathrm{p}, \mathrm{a}}=0.730 \mathrm{~V}$ which corresponded to the oxidation of nickel from $\mathrm{Ni}^{0}$ to $\mathrm{Ni}^{2+}$ and one reduction peak (C1) at the potential, $E_{\mathrm{p}, \mathrm{c}}=0.625 \mathrm{~V}$ which corresponded to the reduction of $\mathrm{Ni}^{2+}$ to $\mathrm{Ni}^{0}$. Obtained peak separation $\Delta E_{\mathrm{p}}$ was $105 \mathrm{mV}$ which pointed to quasi- reversible oxidation

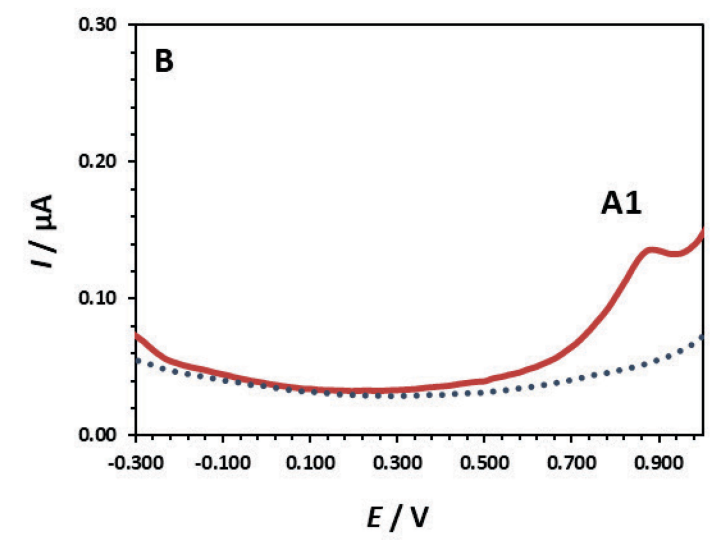

Figure 1. A) Cyclic voltammograms of L-histidine $\left(c=1 \times 10^{-4} \mathrm{~mol} \mathrm{dm}^{-3}\right)$ in a buffer $\mathrm{pH} 4(-), 6(-), 8(-)$ and $10(-)$. Scan rate, $100 \mathrm{mV} \mathrm{s}^{-1}$. B) Differential pulse voltammograms of blank solution $(\cdot . .$.$) and L-histidine (-)\left(c=1 \times 10^{-4} \mathrm{~mol} \mathrm{dm}^{-3}\right)$ in a buffer $\mathrm{pH}$ 10. Scan rate, $5 \mathrm{mV} \mathrm{s}$. 


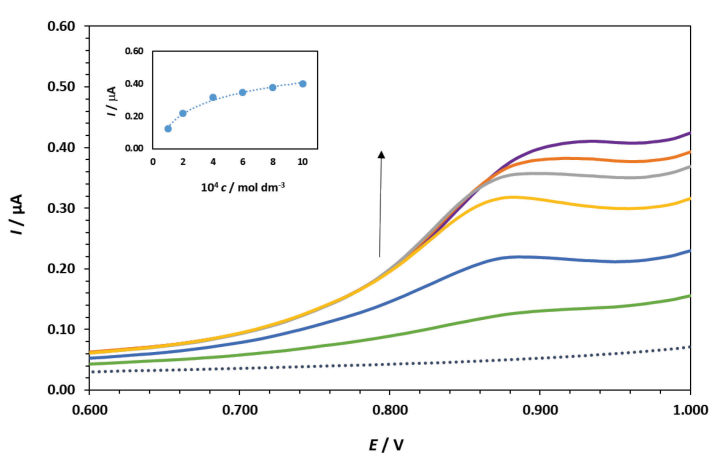

Figure 2. Differential pulse voltammograms of blank solution $(\cdots .$.$) and L-histidine \left(c=1 \times 10^{-4}(-), 2 \times 10^{-4}(-)\right.$, $4 \times 10^{-4}(-), 6 \times 10^{-4}(-), 8 \times 10^{-4}(-)$ and $10 \times 10^{-4}(-)$ mol dm$\left.{ }^{-3}\right)$ in a buffer $\mathrm{pH}$ 10. Scan rate: $5 \mathrm{mV} \mathrm{s}^{-1}$. Inset: Anodic peak current as a function of L-histidine concentration.

process. The cyclic voltammogram of L-histidine solution with nickel in $1: 1$ ratio showed no oxido-reduction peaks of free nickel which could be explained by interactions of Lhistidine with $\mathrm{Ni}^{2+}$ ions in a buffer solution.

\section{DIFFERENTIAL PULSE VOLTAMMETRY}

In order to obtain additional information regarding Lhistidine complexation with $\mathrm{CO}^{2+}$ and $\mathrm{Ni}^{2+}$ ions, differential pulse voltammetry was used. Differential pulse voltammogram of L-histidine (Figure 4) showed one oxidation peak (A1) at the potential $E_{\mathrm{p}, \mathrm{a}}=0.890 \mathrm{~V}$ which corresponded to the oxidation of the imidazole ring. One anodic peak (A2) of cobalt nitrate at the potential $E_{p, a}=$ $0.460 \mathrm{~V}$, which corresponded to the oxidation of cobalt from $\mathrm{Co}^{0}$ to $\mathrm{Co}^{2+}$, was also detected (Figure 4A). Differential pulse voltammogram of L-histidine complex with cobalt in a $1: 1$ ratio revealed one anodic peak (A2) at the potential

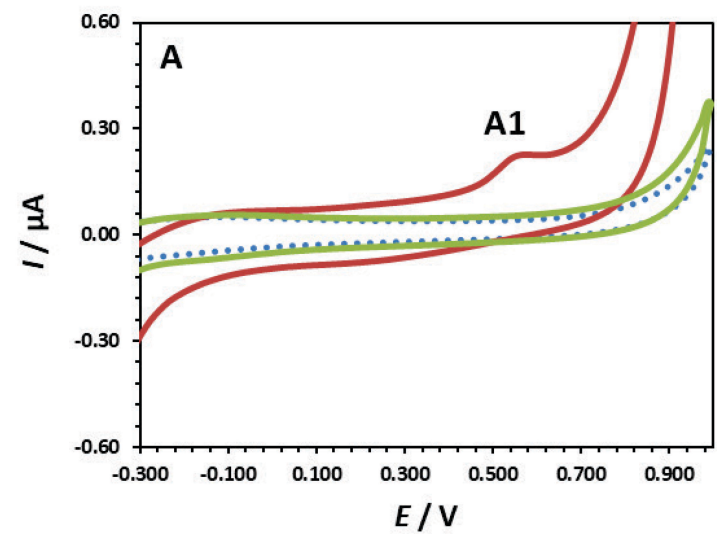

$E_{\mathrm{p}, \mathrm{a}}=0.480 \mathrm{~V}$ which corresponded to cobalt oxidation in a complex. The oxidation peak (A1) which corresponded to Lhistidine imidazole ring oxidation was not detected. Differential pulse voltammogram of nickel nitrate(Figure $4 \mathrm{~B})$ showed one anodic peak (A2) at the potential $E_{\mathrm{p}, \mathrm{a}}=$ $0.700 \mathrm{~V}$ which corresponded to oxidation of nickel from $\mathrm{Ni}^{0}$ to $\mathrm{Ni}^{2+}$. The L-histidine complex with nickel showed two anodic peaks, at the potentials $E_{\mathrm{p}, \mathrm{a}}=0.725 \mathrm{~V}(\mathrm{~A} 3)$ and $E_{\mathrm{p}, \mathrm{a}}=$ $0.865 \mathrm{~V}(\mathrm{~A} 4)$. The first oxidation peak (A3) corresponded to the oxidation of nickel in a complex, while the second oxidation peak (A4) corresponded to the oxidation of imidazole ring.

From the above results can be concluded that imidazole ring and carboxylate group were involved in complexation with metal cations $\left(\mathrm{Co}^{2+}\right.$ and $\left.\mathrm{Ni}^{2+}\right)$. This result agrees with literature data where copper complexation with carnosine and L-histidine at $\mathrm{pH} 10$ was studied and the formation of $1: 1$ complex which involve carboxylate group oxygen and imidazole ring nitrogen was confirmed. ${ }^{[21,26]}$

\section{UV/VIS SPECTROSCOPY}

In Figure 5A UV/VIS absorption spectra of L-histidine, cobalt (II) nitrate and L-histidine complex with $\mathrm{Co}^{2+}$ ion in a $1: 1$ ratio are shown. L-histidine showed an absorbance band in the UV region at $309 \mathrm{~nm}$, which can be assigned to the $\mathrm{n} \rightarrow \pi^{*}$ transition, while the spectra of cobalt (II) nitrate showed absorbance band at $321 \mathrm{~nm}$ which can be assigned to the inter-ligand charge transfer (ILCT) and a broad band at $415 \mathrm{~nm}$ which can be assigned to metal to ligand charge transfer (MLCT). ${ }^{[29]}$ The absorption spectra of $\mathrm{Co}^{2+}$ ion with L-histidine showed an absorbance band at $300 \mathrm{~nm}$ which can be assigned to $\pi \rightarrow \pi^{*}$ transition of the uncomplexed nitrate and an absorbance band at $511 \mathrm{~nm}$ which can be assigned to metal to ligand charge transfer and confirms the formation of $\mathrm{CO}^{2+}$ - L-histidine complex. ${ }^{[30]}$

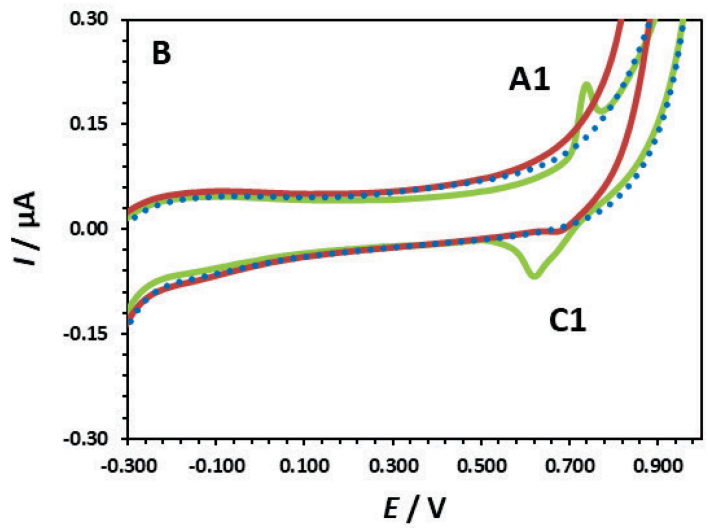

Figure 3. A) Cyclic voltammograms of blank solution (...$\cdot)$, A) $\mathrm{Co}\left(\mathrm{NO}_{3}\right)_{2}(-)$ and $\mathrm{L}$ - histidine complex with $\mathrm{Co}^{2+}$ in a $1: 1$ ratio $(-)$; B) $\mathrm{Ni}\left(\mathrm{NO}_{3}\right)_{2}(-)$ and L-histidine solution with $\mathrm{Ni}^{2+}$ in a $1: 1$ ratio $(-)\left(c=1 \times 10^{-4} \mathrm{~mol} \mathrm{dm}^{-3}\right)$ in a buffer $\mathrm{pH} 10$. Scan rate, $100 \mathrm{mV} \mathrm{s}^{-1}$. 
In Figure 5B UV/VIS absorption spectra of L-histidine, nickel (II) nitrate and L-histidine complex with $\mathrm{Ni}^{2+}$ ion in a $1: 1$ ratio are shown. The spectra of nickel(II) nitrate showed a sharp absorbance band at $300 \mathrm{~nm}$ which can be assigned to the $\pi \rightarrow \pi^{*}$ transition of the uncomplexed nitrate, another sharp absorbance band at the $372 \mathrm{~nm}$ and one broad band at the $620 \mathrm{~nm}$ which can be assigned to $\mathrm{d}-\mathrm{d}$ transitions. ${ }^{[30]}$ The absorption spectra of $\mathrm{Ni}^{2+}$ ion with Lhistidine showed an absorbance band at $300 \mathrm{~nm}$ which can be assigned to $\pi \rightarrow \pi^{*}$ transition of the uncomplexed nitrate, an absorbance band at the $390 \mathrm{~nm}$ which can be assigned to $d-d$ transition and a new broad absorbance band at $720 \mathrm{~nm}$ which can be assigned to metal to ligand charge transfer and confirms the formation of $\mathrm{Ni}^{2+}-\mathrm{L}-$ histidine complex. Based on UV/Vis absorption spectra of both metal cations complexes with L-histidine, we assume that octahedral complexes of $\mathrm{CO}^{2+}$ and $\mathrm{Ni}^{2+}$ with L-histidine were formed in our study. ${ }^{[31,32]}$

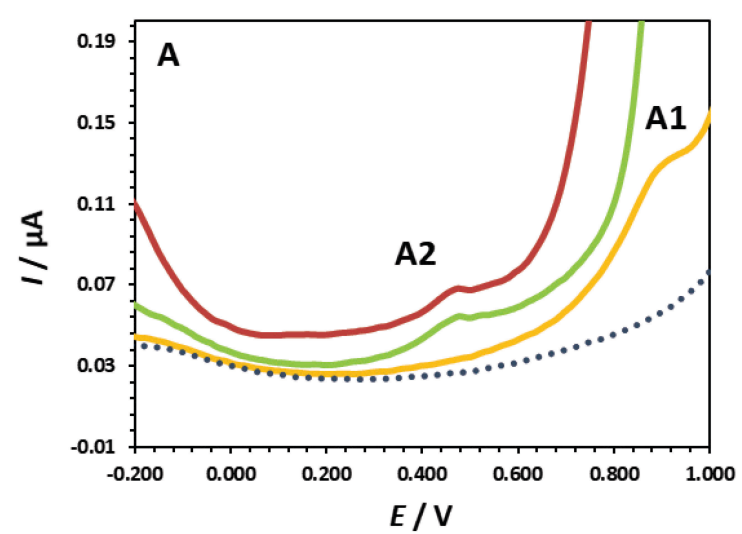

\section{CONCLUSION}

Electrochemical properties of L-histidine were studied by cyclic and differential pulse voltammetry in a $\mathrm{pH}$ range from $\mathrm{pH} 4-10$. The results of cyclic voltammetry have shown that L-histidine was not electroactive in the studied $\mathrm{pH}$ range. Differential pulse voltammetry revealed one anodic peak of L-histidine at $\mathrm{pH} 10$, while no electroactivity in a $\mathrm{pH}$ region from $\mathrm{pH}$ 4-9 was detected. The increase of anodic peak current and anodic peak potential with the increase of L-histidine concentration was also detected. Adsorption of L-histidine oxidation product occurred at concentrations lower than $c \sim 4 \times 10^{-4} \mathrm{~mol} \mathrm{dm}^{-3}$. In a region of higher concentration, increasing interactions between molecules adsorbed on the glassy carbon electrode surface and L-histidine oxidation product molecules, which diffuse from bulk solution to working electrode surface, were observed. Formation of L-histidine complexes with $\mathrm{Co}^{2+}$ and $\mathrm{Ni}^{2+}$ in a

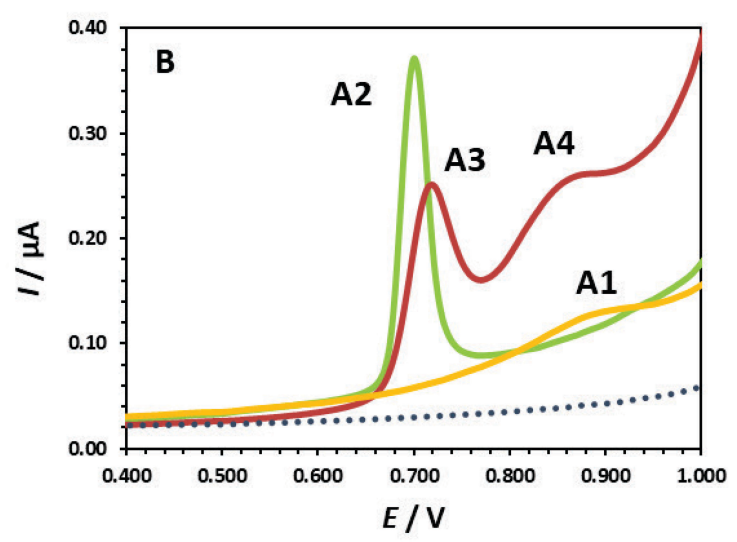

Figure 4. A) Differential pulse voltammograms of blank solution (•...), L-histidine (-) A) Co $\left(\mathrm{NO}_{3}\right)_{2}($ - $)$, and L-histidine complex with $\mathrm{Co}^{2+}$ in a $1: 1$ ratio $(-)$; B) $\mathrm{Ni}\left(\mathrm{NO}_{3}\right)_{2}(-)$ and L-histidine solution with $\mathrm{Ni}^{2+}$ in a $1: 1$ ratio $(-)\left(c=1 \times 10^{-4} \mathrm{~mol} \mathrm{dm}^{-3}\right)$ in a buffer $\mathrm{pH}$ 10. Scan rate, $100 \mathrm{mV} \mathrm{s}^{-1}$.
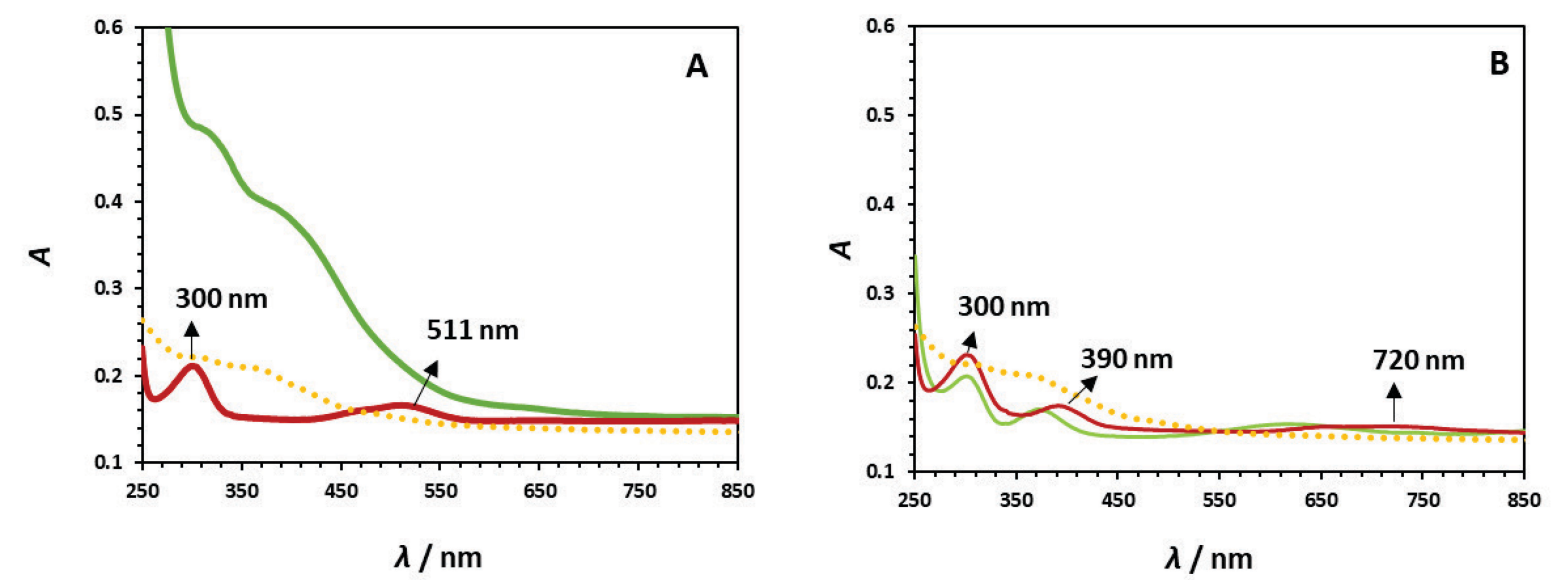

Figure 5. UV/VIS absorption spectra of L-histidine $(\cdots)$, A) $\mathrm{Co}\left(\mathrm{NO}_{3}\right)_{2}(-)$ and $\left.\mathrm{B}\right) \mathrm{Ni}\left(\mathrm{NO}_{3}\right)_{2}(-)$ and their complex with L-histidine in a $1: 1$ ratio $(-), c=4 \times 10^{-3} \mathrm{~mol} \mathrm{dm}^{-3}$ in a buffer $\mathrm{pH} 10$. 
$1: 1$ ratio was confirmed with voltammetric methods (cyclic and differential pulse voltammetry) and UV/VIS spectroscopy. The results have shown that the imidazole ring and carboxylate group of L-histidine were involved in complexation with metal cations $\left(\mathrm{Co}^{2+}\right.$ and $\mathrm{Ni}^{2+}$ ) and that the octahedral complexes were formed. All these findings could find application in alkalosis conditions in small animals (e.g. metabolic alkalosis) when physiological $\mathrm{pH}$ value changes from $\mathrm{pH} 7.4$ to higher values.

\section{REFERENCES}

[1] A. M. Wade, H. N. Tucker, J. Nutr. Biochem. 1998, 9, 308.

[2] C. Guo Nan, W. Xiao Ping, D. Jian Ping, C. Hong Qing, Talanta 1999, 49, 319.

[3] A. Abbaspour, M. A. Kamyabi, Anal. Chim. Acta 2004, 512, 257.

[4] J. Chronopoulos, C. Haidouti, A. Chronopoulou, I. Massas. Sci. Total Environ 1997, 196, 91.

[5] Z. Zdrojewicz, E. Popowicz, J. Winiarski, Pol. Med. J. 2016, 242, 115.

[6] E. Barany, I. A. Bergdahl, L. E. Bratteby, T. Lundh, G. Samuelson, S. Skerving, A. Oskarsson, Environ. Res. 2005, 98, 215.

[7] L. Berk, J. H. Burchenal, W. B. Castle, N. Engl. J. Med 1949, 240, 754.

[8] F. H. Neilsen, Modern Nutrition in Health and Disease (Eds: J. A. Olson, M. Shike), Lea and Febiger, Philadelphia, 1994, pp. 269-286.

[9] I. Grecu, R. Sandulescu, M. Neamtu, Rev. Chim. 1986, 37, 589.

[10] A. I. El-Said, A. S. A. Zidan, M. S. El-Meligy, A. A. Aly, O. F. Mohammed, Synth React Inorg Met Org Chem 2001, 31, 633.

[11] M. Rombach, M. Gelinsky, H. Vahrenkamp, Inorg. Chim. Acta 2002, 334, 25.

[12] V. Kahn, J. Food Biochem. 1999, 23, 409.

[13] E. Farkas, E. A. Enyedy, G. Micera, E. Garribbs, Polyhedron 2000, 19, 1727.
[14] G. W. Chang, E. Snell, Biochemistry 1968, 7, 2005.

[15] S. Tanase, B. M. Guirard, E. Snell, J. Biol. Chem. 1985, 260, 6738.

[16] A. Dondoni, A. Massi., E. Minghini, V. Berolasi, Tetrahedron 2004, 60, 2311.

[17] C. Janiaj, J. Chem. Soc., Dalton Trans. 2000, 21, 3885.

[18] J. J. Gooding, D. B. Hibbert, W. Yang, Sensors 2001, 1,75 .

[19] H. Kumita, K. Jitsukawa, H. Masuda, H. Einaga, Inorg. Chim. Acta 1998, 283, 160.

[20] D. C. Clark, G. T. Cheek, ECS Meeting Abstract 2018, accessed July 18, 2018.

[21] M. Medvidović-Kosanović, A. Stanković, M. Drulak, M. Sak-Bosnar, Int. J. Electrochem. Sci. 2018, 13, 5323.

[22] S. Tanaka, H. Yoshida, J Electroanal Chem 1982, 137, 261.

[23] I. Sovago, E. Farkas, A. Gergely, J. Chem. Soc. Dalton Trans. 1982, 381, 2159.

[24] D. R. Lide, CRC Handbook of Chemistry and Physics, 88th edition. CRC Press, Taylor and Francis Group, Boca Raton, 2008, p. 8-39.

[25] L.-C. Chen, C-C. Chang, H-C. Chang, Electrochim. Acta 2008, 53, 2883.

[26] Y.-C. Weng, T.-H. Cheng, Z. Naturforsch 2011, 66b, 279.

[27] M. Medvidović-Kosanović, M. Šeruga, L. Jakobek, I. Novak, Collect. Czech. Chem. Commun 2010, 75, 547.

[28] Y. S. Ha, K. Hopper, S. E. Epstein, J Vet Intern Med 2013, 27, 847.

[29] D. Basu, S. Mazumder, J. Niklas, H. Baydoun, D. Wanniarachchi, X. Shi, R. J. Staples, O. Poluektov, H. B. Schlegel, C. N. Verani, Chem. Sci. 2016, 7, 3264.

[30] T. E. Klimova, D. Valencia, J. A. Mendoza-Nieto, P. Hernández-Hipólito, J. Catal 2013, 304, 29.

[31] P. J. Morris, R. B. Martin, J. Chem. Soc. A. 1968, 2554, 1543.

[32] L. E. Valenti, C. P. De Pauli, C. E. Giacomelli, J. Inorg. Biochem 2006, 100, 192. 